\title{
KETIMPANGAN DISTRIBUSI PENERIMAAN RUMAH \\ TANGGA PETANI KARET DI DESA MARGO MULYO KECAMATAN PONDOK KUBANG KABUPATEN BENGKULU TENGAH
}

\section{Inequality of Rubber Farmers Household Revenue Distribution in Margo Mulyo Village Pondok Kubang Subdistrict Bengkulu Tengah District}

\author{
Marzuki Afif, Agus Purwoko, dan Nyayu Neti Arianti \\ Jurusan Sosial Ekonomi Pertanian Fakultas Pertanian Universitas Bengkulu \\ afiefmild@gmail.com
}

\begin{abstract}
The purpose of this research are counting the revenue of rubber farming farmers, analyzing sources of household rubber farmer revenue, and analyzing the unequal distribution of household rubber farmer revenue. The location of this research was determine by deliberate consideration that the village Margo Mulyo has GAPOKTAN that active in building village and working for welfare farmers. Data used in this research is primary and secondary data. The results of this research show that the average revenue of rubber farmers is about $\mathrm{Rp}$. 708.278/farmer/month. Based on contributions of farming revenue rubber gives 46 percent, the non farming rubber contribution gives 21 percent, contributions of revenue from non agricultural gives 32 percent. Gini Ratio for the revenue of households rubber farmers in the village Margo Mulyo of 0.45 explain that the unequal distribution of households revenue of the rubber farmers are at moderate level.
\end{abstract}

Keywords: inequality distribution, rubber farmer, gini ratio

\section{PENDAHULUAN}

Perkebunan rakyat menunjukkan peranan yang sangat penting dalam ekonomi di Indonesia. Masyarakat dapat meningkatkan ekonominya atau dapat memperoleh sumber penerimaan melalui perkebunan, dapat diambil pembelajaran dari fenomena ini bahwa perkebunan karet rakyat. Peranan perkebunan ini sangat terasa penting ketika sumbangan devisa untuk negara bisa menutupi sumber devisa lainnya yang sedang mengalami penurunan, selain itu juga sebagai sumber penghasilan keluarga petani (Rani dan Santi, 2011).

Kabupaten Bengkulu Tengah adalah kabupaten yang memiliki potensi untuk pengembangan perkebunan karet rakyat. Kabupaten Bengkulu Tengah memiliki sepuluh kecamatan administrasi yang memiliki peran yang penting untuk usahatani karet rakyat. Data yang bersumber dari “Bengkulu Tengah 
Dalam Angka 2015", perkebunan karet rakyat memiliki luas areal tanam 10.744 Ha, Produksi 9.521 Ton, dan jumlah Petani 7.908 jiwa (Badan Pusat Statistik Bengkulu Tengah, 2015)

Subsektor perkebunan rakyat menjadi sektor andalan mata pencaharian bagi masyarakatnya di Desa Margo Mulyo, Kecamatan Pondok Kubang, Kabupaten Bengkulu Tengah. Usahatani karet merupakan mata pencaharian pokok, selain usahatani padi, sawit, dan ternak. Produksi karet yang sedikit dan harga produk karet yang rendah menyebabkan penerimaan petani menjadi rendah. Akibat dari pada itu petani mencari sumber penerimaan yang lain untuk memenuhi kebutuhan hidupnya.

Perbedaan tingkat ekonomi masyarakat ini disebabkan oleh beranekaragamnya sumber mata pencaharian masyarakat di Desa Margo Mulyo. Sebagian besar berada di sektor nonformal seperti buruh tani, buruh bangunan, petani sawah tadah hujan, perkebunan karet dan kelapa sawit, dan sebagian kecil berada di sektor formal seperti PNS, honorer, guru, tenaga medis, dengan demikian beranekaragamnya sumber mata pencaharian tersebut menjadi salah satu yang dapat mempengaruhi tingkat ketimpangan distribusi penerimaan petani karet. Oleh sebab itu untuk mengetahui lebih lanjut lagi tentang kemungkinan yang ada, maka perlu dilakukan penelitian atau analisis dari penerimaan yang diterima petani karet, dan ketimpangan distribusi penerimaan petani yang terjadi antara rumah tangga petani karet.

Tujuan dari penelitian ini untuk menghitung besarnya penerimaan rumah tangga petani karet rakyat, menganalisis struktur penerimaan rumah tangga petani karet, dan menganalisis ketimpangan distribusi penerimaan rumah tangga petani karet di Desa Margo Mulyo.

\section{METODE PENELITIAN}

\section{Penentuan Lokasi dan Waktu Penelitian}

Penelitian ini dilakukan di Desa Margo Mulyo, Kecamatan Pondok Kubang, Kabupaten Bengkulu Tengah pada bulan Januari sampai Februari 2016. Pemilihan lokasi ini dilakukan dengan sengaja (purposive) atas pertimbangan bahwa di Desa Margo Mulyo terdapat GAPOKTAN yang aktif dalam membangun desa dan mengupayakan kesejahteraan petani seperti mengusulkan berbagai proposal bantuan ke pemerintah sehingga Desa Margo Mulyo sering mendapatkan bantuan dari pemerintah.

\section{Jenis dan Metode Pengumpulan Data}

Data yang diperlukan dan dikumpulkan dalam penelitian ini terdiri dari data primer dan data sekunder. Data primer diperoleh melalui alat yaitu kuesioner yang dilakukan oleh peneliti melalui hasil wawancara dengan responden atau petani sampel, sedangkan data sekunder diperoleh dari studi pustaka atau literatur, internet, instansi atau dinas terkait dan data lain yang berkaitan dengan penelitian yang dilakukan. 


\section{Penentuan Responden}

Penentuan responden untuk petani karet yang menjadi sampel dalam penelitian ini, dilakukan dengan metode sensus sebanyak 50 orang petani karet dengan pertimbangan dan kriteria yaitu: (1) petani karet yang memiliki perkebunan karet yang telah berproduksi dan (2) petani karet tersebut berdomisili di Desa Margo Mulyo.

\section{Analisis Data}

\section{Penerimaan Usahatani Karet}

Adapun dalam penelitian ini digunakan analisis penerimaan petani sesuai dengan rumus yang diformulasikan Soekartawi (2002) sebagai berikut,

$$
\text { TR }=\text { Y . Py }
$$

Dimana:

$$
\begin{aligned}
& \mathrm{TR}=\text { Total penerimaan usahatani karet }(\mathrm{Rp} / \mathrm{bln}) \\
& \mathrm{Y}=\text { Produksi karet }(\mathrm{Kg} / \mathrm{bln}) \\
& \mathrm{Py}=\text { Harga jual karet }(\mathrm{Rp} / \mathrm{Kg})
\end{aligned}
$$

\section{Struktur Sumber Penerimaan Rumah Tangga Petani Karet}

Adanya penerimaan lain, baik dari usahatani maupun luar usahatani, telah memberikan perbaikan struktur dan distribusi penerimaan. Total penerimaan petani dapat dihitung dengan rumus yang diformulasikan (Soekartawi, 2002) sebagai berikut :

$$
\mathrm{Y}=\sum_{i=1}^{n}(\mathrm{P})_{\mathrm{i}}+\sum_{j=1}^{m}(\mathrm{NP})_{\mathrm{i}}
$$

\section{Dimana:}

$\mathrm{Y}=$ Total penerimaan rumah tangga petani karet $(\mathrm{Rp} / \mathrm{bulan})$

$\mathrm{P}=$ Penerimaan dari kegiatan usaha pertanian $(\mathrm{Rp} / \mathrm{bulan})$

$\mathrm{NP}=$ Penerimaan dari usaha non pertanian ( $\mathrm{Rp} / \mathrm{bulan})$

I $=1 \ldots \mathrm{n}=$ usahatani di beberapa sub sektor pertanian dari rumah tangga (Rp/bulan)

$\mathrm{J}=1 \ldots \mathrm{m}=$ non usahatani dari berbagai kegiatan rumah tangga (Rp/bulan)

\section{Analisis Ketimpangan Distribusi Penerimaan}

Tingkat ketimpangan distribusi penerimaan petani karet di Desa Margo Mulyo dianalisis dengan alat analisis Gini Ratio, dan Kurva Lorenz.

\section{Gini Ratio}

Penggunaan alat analisis Gini Ratio ditujukan untuk melihat tingkat ketimpangan distribusi penerimaan rumah tangga petani yaitu dengan metode analisis deskriptif dengan memanfaatkan ukuran-ukuran statistik deskriptif.

$$
\mathrm{GR}=1-\sum_{i=0}^{K} \mathrm{fi}\left(\mathrm{Y}_{\mathrm{i}}+\mathrm{Y}_{\mathrm{i}-1}\right)
$$


ISSN: $1412-8837$

\section{Dimana:}

$$
\begin{aligned}
\mathrm{GR} & =\text { Gini Ratio } \\
\mathrm{K} & =\text { Jumlah Kelas } \\
\mathrm{Fi} & =\% \text { atau proporsi jumlah masyarakat tani dalam kelas ke } \mathrm{i} \\
\mathrm{Y} & =\% \text { atau proporsi penerimaan komulatif dari jumlah peneriman } \\
\mathrm{i} & =\text { Penerimaan masyarakat tani sampai kelas ke } \mathrm{i}
\end{aligned}
$$

Menurut Todaro dan Smith (2003) pengukuran ketimpangan distribusi penerimaan dengan menggunakan alat pengukur ketimpangan Gini Ratio, karena komponen penyusun Gini Ratio dapat digunakan untuk melihat berbagai bagian yang menjadi penyebab ketimpangan yang terjadi berdasarkan bagian penerimaan dan sumber-sumber pendapatan. Kriteria Gini Ratio menurut Todaro dan Smith (2003):

Tabel 1. Katagori Ketimpangan Distribusi Penerimaan

\begin{tabular}{cl}
\hline Katagori Ketimpangan & \multicolumn{1}{c}{ Distribusi Penerimaan } \\
\hline Rendah & Bila angka Gini Ratio berada pada nilai $0-0,35$ \\
Sedang & Bila angka Gini Ratio berada pada nilai 0,36-0,50 \\
Tinggi & Bila angka Gini Ratio berada pada nilai 0,51 - 1 \\
\hline
\end{tabular}

\section{Kurva Lorenz}

Metode lazim lainnya yang digunakan untuk menganalisis tingkat penerimaan seseorang adalah dengan menggunakan kurva Lorenz (Lorenz Curve). Jumlah penerimaan pendapatan dinyatakan pada sumbu horizontal yang digambarkan dalam persentase komulatif, sedangkan sumbu vertikal menyatakan bagian dari penerimaan total yang diterima oleh masing-masing persentase kelompok penduduk tersebut. Sumbu tersebut berakhir pada titik 100 persen, sehinga itu kedua sumbu (vertikal dan horizontal) sama panjangnya.

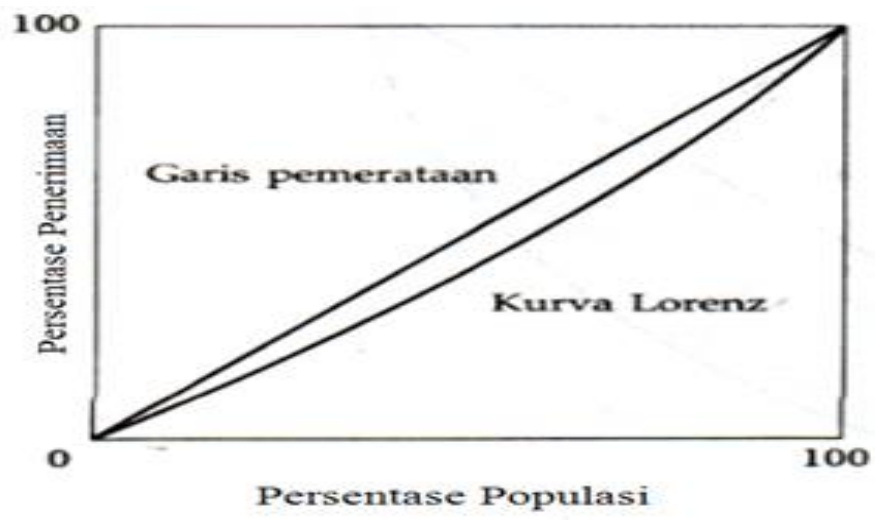

Gambar 1. Kurva Lorenz

Sumber: Todaro dan Smith (2003)

180 | Marzuki Afif, Agus P., dan Nyayu N.A., Ketimpangan Distribusi... 


\section{Kriteria Ketimpangan menurut Bank Dunia}

Menurut Makmur (2011) ketimpangan distibusi pendapatan menurut Bank Dunia dapat diukur dengan cara menghitung jumlah persentase dari pendapatan yang diterima masyarakat dari kelompok dengan pendapatan rendah dibandingkan dengan jumlah total pendapatan penduduk. Kriteria Bank Dunia tersebut akan membagi pendapatan dari masyarakat yang diurutkan pendapatan terendah ke pendapatan yang tertinggi setelah itu dibagi mejadi 3 katagori yaitu :

\section{Tabel 2. Katagori Ketimpangan menurut Kriteria Bank Dunia}

Katagori

Ketimpangan

Distribusi Penerimaan

$\begin{array}{ll}\text { Tinggi } & 40 \text { persen terendah menerima penerimaan kurang dari } \\ & 12 \% \text { dari total penerimaan. } \\ \text { Sedang } & 40 \text { persen sedang terhadap penerimaan total antara } \\ & 12 \%-17 \% \text { dari total penerimaan. }\end{array}$

Rendah 20 persen tertinggi terhadap penerimaan seluruh masyarakat lebih besar dari $17 \%$ dari total penerimaan.

\section{HASIL DAN PEMBAHASAN}

\section{Penerimaan Usahatani Karet}

Penerimaan adalah jumlah produksi yang dikalikan dengan harga yang berlaku pada saat penelitian berlangsung di Desa Margo Mulyo.

Tabel 3. Rata-rata Penerimaan Petani Usahatani Karet di Desa Margo Mulyo

\begin{tabular}{lcc}
\hline \multicolumn{1}{c}{ Uraian } & Per UT/Bln & Per/Ha/Bln \\
\hline Produksi $(\mathrm{Kg} / \mathrm{bln})$ & 141 & 220 \\
Harga (Rp/bln) & 5.004 & 5.004 \\
Penerimaan $(\mathrm{Rp} / \mathrm{bln})$ & 708.278 & 1.106 .905 \\
\hline
\end{tabular}

Sumber: Data primer diolah, 2016

Rata-rata penerimaan petani karet dari hasil usahatani karet sebesar Rp. 708.278/UT/Bln atau Rp. 1.106.905/Ha/Bln. Informasi yang didapat dari daerah peneltian bahwa penerimaan yang diterima petani karet tersebut termasuk kecil untuk memenuhi kebutuhan kehidupan petani dalam sebulannya. Kecilnya penerimaan petani dari usahatani karet tersebut dipengaruhi oleh luas lahan, jenis bibit, penggunaan pupuk, dan harga produk. Fenomena di daerah penelitian harga yang berlaku yaitu rata-rata harga sebesar Rp. 5004/kg. Informasi dari petani karet harga tersebut merupakan harga yang sangat rendah bila dibandingkan harga karet pada tahun 2012. Menurut Wijayanti dan Saefuddin (2012) bahwa harga karet satuan per kg tahun 2012 sebesar Rp 13.000. Terlihat perbandingan harga pada 
saat penelitian dan harga sebelumnya terdapat perbedaan harga yang cukup jauh.

\section{Struktur Penerimaan Rumah Tangga Petani Karet Di Desa Margo Mulyo.}

Beragamnya sumber penerimaan rumah tangga tangga petani karet karena tuntutan untuk memenuhi kebutuhan hidup yang semakin kompleks dan juga untuk meningkatkan taraf hidup petani.

\begin{tabular}{lrc}
$\begin{array}{l}\text { Tabel 4. Struktur Rata-rata Penerimaan Rumah Tangga Petani Karet di Desa } \\
\text { Margo Mulyo }\end{array}$ & & \\
\hline Sumber Penerimaan & & \\
\hline 1. Pertanian & & \\
a. Usahatani Karet & 708.278 & 24,97 \\
b. Non Usahatani Karet & 800.630 & 28,22 \\
Total Penerimaan Pertanian (a+b) & 1.508 .908 & 53,19 \\
2. Non Pertanian & 1.327 .700 & 46,81 \\
\hline Total Penerimaan Rumah Tangga (1+2) & 2.836 .608 & 100,00 \\
\hline
\end{tabular}

Sumber: Data primer diolah, 2016

Pemenuhan kebutuhan kehidupan petani karet sehari-hari sendiri selain bersumber dari usahatani karet, petani karet juga mencari sumber penerimaan yang lain seperti sumber penerimaan dari non usahatani karet, dan non pertanian. Penerimaan petani karet dari usahatani karet memberikan kontribusi sebesar 24,97\%. Meskipun usahatani tani karet merupakan mata pencaharian pokok petani karet di Desa Margo Mulyo, tetapi pada kenyataan penerimaan dari usahatani karet paling kecil dari sumber penerimaan lainya yaitu sebesar Rp. 708.278/bln. Hal ini disebabkan harga karet pada saat penelitian sangat rendah yaitu $\mathrm{Rp} 500 / \mathrm{kg}$ selain produksi yang juga rendah akibat kemarau yang panjang. Hasil penerimaan dari usatahani karet ini tentu saja tidak mencukupi kebutuhan hidup rumah tangga petani karet. Sumber penerimaan lainnya yang berasal dari non usahatani karet, seperti kelapa sawit, ternak, padi, buah jeruk, dan sayur memberikan kontribusi penerimaan rumah tangga petani karet sebesar $28,22 \%$ atau Rp. 800.630/bln. Sementara itu, kontribusi penerimaan dari non pertanian sebesar $46,81 \%$ atau Rp. $1.327 .700 /$ bln. Dengan demikian, total penerimaan rumah tangga petani karet dari ketiga sumber penerimaan tersebut sebesar Rp. 2.836.608/bln.

\section{Ketimpangan Distribusi Penerimaan Rumah Tangga Petani Karet}

Gini Ratio untuk penerimaan rumah tangga petani karet sebesar 0,45 yang merupakan seluruh penerimaan rumah tangga petani karet di Desa Margo Mulyo. Nilai Gini Ratio tersebut menjelaskan bahwa ketimpangan distribusi penerimaan rumah tangga petani karet berada di tingkat ketimpangan sedang. Terjadinya ketimpangan antar rumah tangga petani karet tersebut disebabkan berbedanya keragaman sumber penerimaan petani karet dari sumber penerimaan non usahatani karet dan sumber penerimaan 
non pertanian. Seperti diketahui yang menyebabkannya adalah petani karet yang hanya melakukan satu komoditi usahatani akan berbeda penerimaannya dengan rumah tangga petani karet yang melakukan usahatani lebih dari satu jenis usahatani. Selain itu, penerimaan non pertanian juga menyababkan perbedaan penerimaan antara rumah tangga petani karet satu dengan yang lainya. Sejalan dengan penelitian Karundeng (2015), Indeks Gini dari total usaha pertanian dan non pertanian diperoleh sebesar 0.4366 yang berada pada ketidakmerataan sedang. Penyebab terjadi ketimpangan itu karena perbedaan penguasaan sumber daya, dan petani yang kaya tentunya punya modal, punya pendidikan tinggi, dan punya lahan besar. Sementara itu, petani yang berpendapatan rendah tentu saja penguasaan sumber dayanya juga rendah, sehingga terjadi ketimpangan karena perbedaan pemilikan sumberdaya.

\section{Kurva Lorenz}

Hasil angka ketimpangan yang didapat dengan penggunaan analisis Gini Ratio, selanjutnya digunakan untuk mengetahui gambaran ketimpangan penerimaan yang terjadi antar rumah tangga petani karet di Desa Margo Mulyo dengan menggunakan metode Kurva Lorenz. Kurva Lorenz tersebut akan membandingkan antara persentase penerimaan dengan persentase populasi.

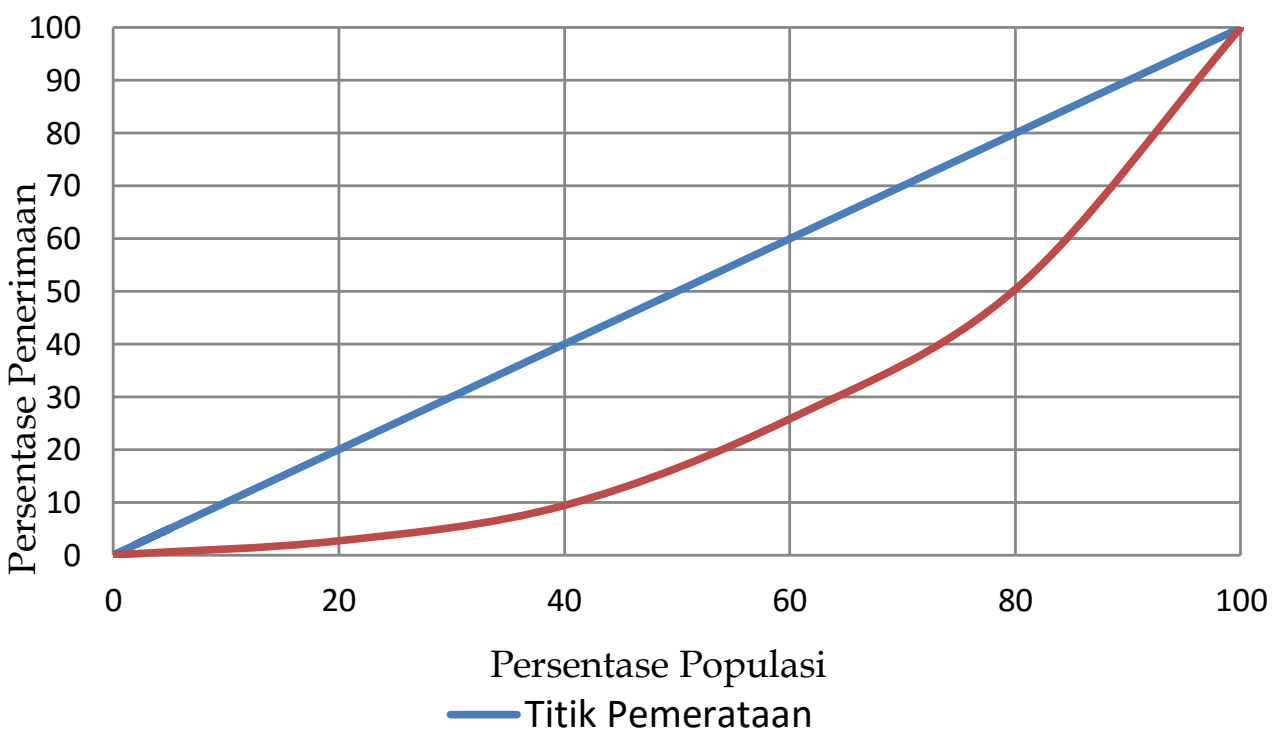

\section{Gambar 2. Kurva Lorenz Rumah Tangga Petani Karet di Desa Margo Mulyo Sumber: Data primer diolah, 2016}

Kurva Lorenz memperlihatkan penyebaran distribusi penerimaan antara kelompok rumah tangga petani karet, kelompok rumah rumah tangga dibagi menjadi Desile 5 kelompok penerimaan masing-masing kelompok di bagi $20 \%$. 
jumlah rumah tangga petani karet yang diurutkan berdasarkan penerimaan terendah sampai penerimaan tertinggi. Dua puluh persen $(20 \%)$ pertama menerima jumlah penerimaan sebesar Rp. 3.795.400/bln dengan persentase $2,7 \%$ dari total penerimaan, dua puluh persen (20\%) kedua menerima penerimaan sebesar Rp. 9.524.00/bln dengan persetase $6,7 \%$ dari total penerimaan. 20\% ketiga menerima penerimaan sebesar Rp. 23.293.000/Bln dengan persetase $16,4 \%$ dari total penerimaan, dan dua puluh persen $(20 \%)$ keempat menerima penerimaan sebesar Rp. 34.850.99/Bln dengan persetase $24,6 \%$ dari total penerimaan. $20 \%$ kelima menerima penerimaan sebesar Rp. 70.367.000/Bln dengan persetase 6,7\% dari total penerimaan. Gambar 4 bahwa Kurva Lorenz menggambar persentase penerimaan antara rumah tangga petani karet di Desa Margo Mulyo. Kurva Lorenz yang didapat menjauhi garis diagonal (garis pemerataan), dan Kurva Lorenz tersebut menggambarkan distibusi penerimaan antara rumah tangga petani karet di Desa Margo Mulyo berada dalam katagori sedang.

\section{Kriteria Bank Dunia}

Ketimpangan distibusi pendapatan menurut bank dunia dapat diukur dengan cara menghitung jumlah persentase dari pendapatan yang diterima masyarakat mulai dari kelompok dengan penerimaan rendah dibandingkan dengan jumlah total pendapatan penduduk. Kriteria bank dunia tersebut akan membagi penerimaan dari masyarakat yang diurutkan pendapatan terendah ke pendapatan yang tertinggi. Seperti tertera pada Tabel 15 ketimpangan berdasarkan kriteria Bank Dunia.

Tabel 5. Ketimpangan Berdasarkan Bank Dunia di Desa Margo Mulyo

\begin{tabular}{cccc}
$\begin{array}{c}\text { Kelompok Rumah Tangga } \\
\text { Petani Karet }\end{array}$ & $\begin{array}{c}\text { Jumlah } \\
\text { Petani } \\
(\mathrm{Jiwa})\end{array}$ & $\begin{array}{c}\text { Jumlah } \\
\text { Penerimaan } \\
(\mathrm{Rp} / \mathrm{Bln})\end{array}$ & $\begin{array}{c}\text { Persentase } \\
\text { Penerimaan } \\
(\%)\end{array}$ \\
\hline 140 Penerimaan erendah & 20 & 13.319 .400 & 9,4 \\
& 20 & 58.143 .999 & 41,0 \\
$240 \%$ Penerimaan Sedang & 10 & 70.367 .000 & 49,6 \\
\hline 3 20\% Penerimaan Tertinggi & 10 & 141.830 .400 & 100,0 \\
\hline Jumlah & 50 & &
\end{tabular}

Sumber: Data primer diolah, 2016

Kriteria Bank Dunia jika persentase jumlah penerimaan 40 persen terendah menerima penerimaan kurang dari $12 \%$ dari total penerimaan maka distribusi penerimaan diartikan memiliki ketimpangan tinggi. Jika persentase penerimaan 40 persen sedang terhadap penerimaan total antara $12-17 \%$, maka distribusi penerimaan diartikan memiliki ketimpangan sedang, dan jika persentase penerimaan 20 persen tertinggi terhadap penerimaan seluruh 
masyarakat lebih besar dari 17\% maka distribusi pendapatan digolongkan rendah (Makmur, 2011)

Berdasarkan kriteria Bank Dunia terdapat tiga kelompok penerimaan diurutkan berdasarkan penerimaan terendah sampai penerimaan yang tertinggi. Tabel 5 menunjukkan bahwa $40 \%$ penerimaan terendah rumah tangga petani karet di Desa Margo Mulyo yaitu sebesar 9,4\% terhadap total penerimaan rumah tangga petani karet. Dengan demikian, katagori ketimpangan menurut Kriteria Bank Dunia bila 40\% penerimaan terendah kurang $12 \%$ dari total penerimaan maka distribusi penerimaan rumah tangga petani karet di Desa Margo Mulyo dengan ketimpangan tinggi atau tidak merata. Golongan $40 \%$ penerimaan rumah tangga petani karet dengan katagori sedang memperlihatkan $41 \%$ dengan jumlah penerimaan sebesar Rp. $58.143 .999 /$ bln terhadap total penerimaan. Penerimaan tersebut lebih besar dari $17 \%$, maka antar rumah tangga petani karet mengalami ketimpangan sedang. Terakhir, golongan $20 \%$ penerimaan tertinggi rumah tangga petani karet menerima $49,6 \%$, sehingga antar rumah tangga petani karet mengalami ketimpangan rendah karena menerima lebih dari $17 \%$ penerimaan dari total penerimaan.

Oleh karena itu, perlu dilakukan perbaikan-perbaikan sehingga dapat mengurangi ketimpangan yang ada yaitu dengan pilihan kebijakan. Menurut Todaro dan Smith (2003) negara berkembang seperti Indonesia yang berkeinginan untuk menuntaskan masalah kemiskinan yang sangat kompleks serta bagaimana menanggulangi bila terjadi ketimpangan distibusi pendapatan haruslah mengetahui bagaimana pilihan-pilihan cara yang tersedia dan memilih yang terbaik di antaranya untuk mencapai tujuan-tujuan yang ingin dicapai. Beberapa bidang pemerintah dapat melakukan intervensi, yaitu terdapat empat bidang yang memungkinkan pemerintah melakukan intervensi kebijakan yaitu mengubah distribusi fungsional, memeratakan distribusi ukuran, golongan penduduk berpenghasilan tinggi, dan memeratakan distribusi ukuran golongan penduduk yang berpenghasilan rendah.

Pertama, mengubah distribusi fungsional yang memiliki tujuan adalah bagaimana pengaruh dari harga terhadap tingkat ketimpangan distribusi. Keadaan yang terjadi pada fenomena saat penelitian bahwa penerimaaan rumah tangga petani karet dari usahatani karet tergolong rendah dikarenakan harga yang berlaku pada saat penelitian juga rendah. Oleh karena itu, dengan harga yang rendah tersebut petani karet menerima penghasilan dari usahatani karet juga rendah. Selain itu juga sumber penerimaan ada dikalangan rumah tangga petani karet hanya satu sumber penerimaan yaitu hanya dari usahatani karet saja. Bila dibandingkan dengan petani yang memiliki sumber penerimaan lebih dari satu maka kedua petani tersebut terjadi ketidakmerataan penerimaan.

Selain harga hasil usahatani karet, pengaruh harga juga terdapat pada sumber penerimaan non pertanian, dengan harga karet yang rendah petani banyak bekerja menjadi buruh, buruh tani maupun buruh bangunan. Harga 
upah tenaga kerja di sektor non formal tersebut tidak pernah diberlakukan seperti pada sektor formal, sehingga beberapa petani yang memiliki sumber penerimaan dari formal seperti honor dan PNS maka terdapat ketidakmerataan penerimaan antar rumah tangga petani karet di Desa Margo Mulyo.

Kedua, memeratakan distribusi ukuran yang didasarkan pada kepemilikan dan penguasaan atas aset produktif. Penyebab nomor satu atas timpangnya distribusi pendapatan perkapita di hampir semua negara berkembang adalah sangat tidak meratanya kepemilikan aset (asset ownership) kekayaan di negara berkembang tersebut (Todaro dan Smith, 2003).

Rumah tangga yang memiliki aset produktif sebagai sumber penerimaan yang sedikit maka pengaruh terhadap penerimaan yang diterima rumah tangga petani tersebut juga sedikit, begitu halnya juga bila rumah tangga petani memiliki aset-aset produktif yang lebih banyak dari rumah tangga petani lainnya maka penerimaannya juga lebih banyak. Penguasaan kepemilikan aset pada lahan untuk usahatani karet, terdapat perbedaan luas lahan yang diusahakan, perbedaan luas lahan tersebut akan berpengaruh terhadap hasil produksi usahatani karet tersebut.

Ketiga, meratakan distribusi ukuran golongan penduduk berpenghasilan tinggi, yaitu dengan adanya pemberlakuan pajak yang berkelanjutan terhadap pendapatan dan kekayaan masing-masing pribadi. Dengan pemberlakukaan pajak tersebut diharapkan adanya penerimaan kepada pemerintah daerah sebagai sumber potensial sehingga pemerintah mendapat sumber pendapatan yang bisa digunakan untuk program-program yang berdampak kepada perbaikan ketimpangan distribusi penerimaan yang terjadi pada rumah tangga petani karet .

Keempat, meratakan distribusi ukuran golongan penduduk yang berpenghasilan rendah. dimana pengeluaran atau aggaran yang didapat dari pajak maka sumber tersebut yang tujuannya untuk meningkatkan taraf hidup rumah tangga berpenghasilan rendah atau miskin yang diterima secara langsung, contohnya dengan bantuan pembayaran transfer seperti BLT, BPJS atau yaitu melalui penciptaan lapangan kerja, sekolah gratis, pelayanan kesehatan.

Berdasarkan keempat bidang yang telah dijelaskan tersebut diharapkan pemerintah sebagai penentu kebijakan-kebijakan dapat memikirkan menemukan suatu cara yang baik sehingga bisa mempengaruhi keadaan perekonomi masyarakat yang berpenghasilan rendah atau miskin dan bisa memperbaiki ketimpangan distribusi penerimaan yang terjadi di masyarakat khususnya antara rumah tangga petani karet di Desa Margo Mulyo. 


\section{SIMPULAN DAN SARAN}

\section{Simpulan}

Berdasarkan hasil penilitian dan analisis data serta pembahasan yang dilakukan, maka dapat ditarik kesimpulan yaitu:

1. Rata-rata besarnya penerimaan petani dari usahatani karet yaitu sebesar Rp. 708.278/bln.

2. Struktur penerimaan rumah tangga petani karet berasal dari berbagai kegiatan yaitu dari usahatani karet sebesar 24,97\%, non usahatani karet sebesar $28,22 \%$, dan non pertanian sebesar $46,81 \%$.

3. Ketimpangan distribusi penerimaan rumah tangga petani karet di Desa Margo Mulyo dengan menggunakan Gini Ratio yaitu masuk ke dalam katagori ketimpangan sedang nilai Gini Ratio sebesar 0,45.

\section{Saran}

1. Rumah tangga petani karet berpenghasilan rendah sebaiknya mencari sumber penerimaan di luar usahatani karet, sehingga dapat membantu perekonomian keluarga yang tujuannya untuk memenuhi kebutuhan hidup yang baik.

2. Pemerintah daerah Bengkulu diharapkan mampu menemukan cara atau memberikan suatu kebijakan-kebijakan yang dapat membantu rumah tangga petani karet dalam berusahatani karet, terutama kestabilan harga.

\section{DAFTAR PUSTAKA}

Badan Pusat Statistik Bengkulu Tengah. 2015. Bengkulu Tengah dalam Angka 2015. http://BPS. Bengkulu tengah.co.id. Diakses pada tanggal 18-102015.

Karundeng, Philips, H. 2015. Distribusi Pendapatan Petani Di Desa Kapataran Satu Kecamatan Lembean Timur. pdf.http://ejournal.unsrat.ac.id. Diakses pada tanggal 22-10-2015.

Makmur, T. 2011. Ketimpangan Distribusi Pendapatan Rumah Tangga Masyarakat Desa di Kecamatan Peukan Bada Kabupaten. Agrisep Vol. (12) : 1 - 10 .

Rani, A.P., dan A.W.N. Santi. 2011. Sistem Distribusi Hasil Pertanian Karet di Desa Mandiangin Barat. Jurnal Spread. 1 (1): 1-8.

Soekartawi. 2002. Prinsip Dasar Ekonomi Pertanian Teori Dan Aplikasi. PT Raja Grafindo Persada. Jakarta.

Todaro, Michael P., dan Smith, C.S. 2003. Pembangunan Ekonomi Dunia Ketiga. Edisi Kedelapan. Erlangga. Jakarta.

Wijayanti, T., dan Saefuddin. 2012. Analisis Pendapatan Usahatani Karet (Hevea Brasiliensis) di Desa Bunga Putih Kecamatan Marang Kayu Kabupaten Kutai Kartanegara. Ziraa'ah, Vol. (34) : 137-149. 
